\title{
The Interactive Effect of Communication and Stress on Perception of Quality of Work Life
}

\author{
${ }^{1}$ Alam Sageer, ${ }^{2}$ Dr. Sameena Rafat \\ ${ }^{1}$ (Department of Management, CMJ University, Shillong India) \\ ${ }^{2}$ (Department of Management, IIPM, Lucknow India)
}

\begin{abstract}
Communication competence is considered essential for communicators in an organization. Inadequate and incomplete communication creates stress among employees as regards to organizational role. Employees basically work for having a balance between organizational objectives and individual needs. High degree of perception of quality of work life leads to satisfied, and committed workforce. The present paper aims to discuss the interactive effect of communication and stress on perception of $Q W L$.
\end{abstract}

Key words: Quality of Work Life (QWL), Employee Stress, Communication

It is universally accepted by both management and practitioners and researchers that the success of any organization is highly dependant on how it attracts, recruits, motivates, and retains its workforce. Today's organizations need to be more flexible so that they are equipped to develop their workforce and enjoy their commitment. Therefore, organizations are required to adopt a strategy to improve the employees "quality of work life'(QWL) to satisfy both the organizational objectives and employee needs. The role and importance of a good quality of work life of employees in an organization are viewed with respect to effective communication which reduces stress while one is on the job or off the job.

We shall thus first enunciate the basics of both stress and communication and then try to correlate them in our endeavour to understand and discuss the importance of having effective quality of work life practices in organizations and their impact on employee performance

Quality of Working Life is a term that had been used to describe the broader job-related experience an individual has. But it can not afford to ignore off- the -job experiences .Non working hours can not be categorically detached from the working hours as an employee unconsciously carries the work experience to home. Hence it is the overall perception of QWL which makes an individual committed to the work place to give most possible performance.

Quality of work life (QWL) is viewed as an instrument of managing people. The QWL approach considers people as an 'asset' to the organization rather than as 'costs'. It believes that people perform better when they are allowed to participate in managing their work and make decisions.

Quality of Life is the extent of relationships between individuals and organizational factors that exist in the working environment. Quality of work life is the extent to which workers can satisfy important personal needs through their experiences in the organization. It is focusing strongly on providing a work environment conducive to satisfy individual needs. It is assumed that if employees have more positive attitudes about the organization and their productivity increases, everything else being equal, the organization should be more effective. Successful organizations support and provide facilities to their people to help them to balance the scales as to what they perceive and what they receive.

The term quality of work life refers to the favorableness or un-favourableness of a total job environment for people (Davis and Newstrom 1985). The basic purpose is to develop jobs and working conditions that are excellent for people as well as for the economic health of the organization. The elements in QWL program include-open communication, equitable reward systems a concern for employee job security and satisfying careers and participation in decision making.

QWL programs usually emphasize development of employee skills, the reduction of occupational stress and development of labor management relations. Several researches have been conducted in this field. Sayeed and Sinha (1981) examined the relationship between QWL, job stress and performance. The results indicate that higher QWL leads to greater job satisfaction.

In an organization we have people with diverse background, varied cultural values, different skills and qualifications and contrasting experiences .In spite of all diversities, one thing which binds them together as a great asset is nothing but communication. The stress caused due to inaccuracy and inadequacy of communication may lead to sense of alienation.

This also puts a question on their loyalty for the company. Here comes the role of employee communication. Effective communication is thus, critical to the organization as it directly affects the organizational performance. 
The work related factors predominantly requiring the communication competence are the working environment, supervision, and participation in decision making

Effective communication enhances the capacity to convey information .It transmits information not only about tangible fact but also about emotions. When an employee transmit some information , he/she may intentionally or unconsciously be communicating his attitude or frame of his or her mind.

Communication competence is considered essential not only for managers rather addressee too. It is the specific skill and abilities that basically create an effective communication environment vis -a vis open working environment.

Let us now understand the different kind of organizational stress-

Stress arises from a lack of fit between a person and its environment, if the person finds it difficult to cope with the constraints or demands encountered (Harrison, 1976).Stress can result from an opportunity, threat or challenge when the outcomes of the episode is uncertain but important ( Robbins and Sanghi, 2006).

The major stress experienced in the organization may be related to organizational role and ineffective communication which would otherwise help the employees know the organization better.

Organizational role (Pareek .1993 pp 3-20) is defined by the expectations which the significant people in the organization have from the role occupant. Role integrates the role occupant with the organization. Role occupant performs certain functions in response to his/her role expectations. Many a times the employees do not know exactly as to what is really expected from them in order to balance the individual objectives and organizational objectives. In this kind of ambiguity, while performing in a role, occupant invariably faces a number of problems. Quality of defined organizational role, therefore, is a potential source of stress. Stress experienced in an organizational role is known as Organizational Role Stress (ORS).

What really employees need to be given information and knowledge about in order to comprehensively define and explain the work expected from him, are-

- Information about the organization with respect to its business, products or services ,key persons to solve the problems along with organizational values and philosophies.

- Information about his/her job profile as to what is he /she expected to perform. Job specification and what are the skills and resources required for the same.

- Information about the team consists of supervisors, group leader and peers with whom one has to interact very often.

The knowledge about all the components, stated above inculcate in employees a sense of worth and belongingness with the organization. Effective communication produces confidence and make one realize that he /she will be given heed to, respected, trusted and valued by the organization.

There are different forms of communication like Information, advice, order, suggestion ,persuasion ,education, warning , moral boosting, motivation that are practiced every day in organizational life. They have to be essentially effective to create an amicable and free working environment contributing to better perception of QWL.

Table showing impact of effective communication

\begin{tabular}{|c|c|c|c|c|}
\hline S.N & $\begin{array}{l}\text { Forms of } \\
\text { Communication }\end{array}$ & $\begin{array}{l}\text { Effective } \\
\text { Communication }\end{array}$ & Outcome & Impact \\
\hline 1. & Information & $\begin{array}{l}\text { Factual } \\
\text { understanding about } \\
\text { organisation }\end{array}$ & $\begin{array}{lr}\begin{array}{l}\text { Clarity about } \\
\text { nature }\end{array} \\
\begin{array}{l}\text { objectives and } \\
\text { organization }\end{array}\end{array}$ & \multirow{5}{*}{$\begin{array}{l}\text { Effective mode of communication } \\
\text { will definitely lead to reduce the } \\
\text { tension and stress related to } \\
\text { ambiguity of the situation and } \\
\text { working environment where one has } \\
\text { to perform to exist in the } \\
\text { organization. Any communication } \\
\text { practice based on the basics of } \\
\text { effective communication will } \\
\text { gradually minimize the different } \\
\text { socio-psychological blocks on part of } \\
\text { communicators. Experiences related } \\
\text { to organizational role will be less } \\
\text { stressed .A balance between } \\
\text { organizational objectives and } \\
\text { employees needs, will lead to high } \\
\text { degree of perception of QWL. }\end{array}$} \\
\hline 2. & Advice & $\begin{array}{l}\text { Influence one's } \\
\text { opinion and attitude }\end{array}$ & $\begin{array}{lr}\text { Change } & \text { in } \\
\text { behaviour } & \text { for } \\
\text { better results } & \\
\end{array}$ & \\
\hline 3. & Order & $\begin{array}{l}\text { Complete } \\
\text { instruction and } \\
\text { direction in non- } \\
\text { authoritative } \\
\text { manner as per level } \\
\text { of receiver }\end{array}$ & $\begin{array}{l}\text { Task completion } \\
\text { with minimum } \\
\text { possible error. }\end{array}$ & \\
\hline 4. & Suggestion & $\begin{array}{l}\text { Constructive } \\
\text { suggestions }\end{array}$ & Better functioning & \\
\hline 5 . & Persuasion & $\begin{array}{l}\text { Influence feeling, } \\
\text { attitude, or belief }\end{array}$ & $\begin{array}{l}\text { Win over and } \\
\text { convince others to } \\
\text { avoid conflicting } \\
\text { situation }\end{array}$ & \\
\hline
\end{tabular}


The Interactive Effect of Communication and Stress on Perception of Quality of Work Life

\begin{tabular}{|c|c|c|c|}
\hline 6. & Education & $\begin{array}{ll}\begin{array}{l}\text { Leads to learning } \\
\text { and }\end{array} & \text { capacity } \\
\text { building } & \\
\end{array}$ & $\begin{array}{l}\text { Skill up- gradation } \\
\text { to meet the } \\
\text { challenges }\end{array}$ \\
\hline 7. & Warning & $\begin{array}{l}\text { Makes an employee } \\
\text { careful }\end{array}$ & $\begin{array}{l}\text { Avoid unpleasant } \\
\text { situation of lay off }\end{array}$ \\
\hline 8. & Moral Boosting & $\begin{array}{l}\text { Inculcates discipline } \\
\text {,high spirit and } \\
\text { confidence }\end{array}$ & $\begin{array}{l}\text { Better } \\
\text { performance } \\
\text { especially in odd } \\
\text { situations }\end{array}$ \\
\hline 9. & Motivation & $\begin{array}{l}\text { Develop an inner } \\
\text { urge to make effort }\end{array}$ & $\begin{array}{l}\text { Improved } \\
\text { performance }\end{array}$ \\
\hline
\end{tabular}

It is being observed that even though a company has a brand equity in the market, however, it fails to be the same in eyes of its own employees. The employees are not able to carry the image because they do not perceive the quality of work life as positive. The employee communication, thus, should aim towards having a common consensus about the organization in the minds of its employees. It should be promoting loyalty among employees, provide better quality of work life that satisfies their needs, and encourage employees to represent the company in a manner consistent with the image defined in the market. Moreover, the company should work towards promoting transparency and openness in employee communication.

Employee communication is directly linked with the success of an organization. Generally, effective employee communication is linked to productivity and morale of the employees. The effective the communication, lesser the organizational stress, the better is the performance. Employees, today, want to have access to concrete information.

Researches have revealed that effective communication has a positive impact on employee satisfaction, productivity, turnover, and morale. Research shows that employees are most highly motivated and make their best contribution to the business when there is full and open communication at work. It is also proved that where there is an adequate and free flow of information and ideas among employees, productivity is enhanced and ambiguity, duplication, and non performing conflict are minimized. Moreover, employee communication should not be seen as impersonal and a formality of dissemination of information among the employees. It should be considered to be an empathetic transfer of understanding and deeper feelings.

Thus for all practical purposes, it can be concluded that the interactive effect of communication and stress plays an extremely decisive role on the perception of QWL. QWL programmes stressing effective communication will contribute to have efficient, satisfied and committed work force.

\section{References-}

[1] Sinha P. \& Sayeed O. B. (1980), "Measuring QWL in relation to job satisfaction \& performance in two organization, "Managerial Psychology, 2, 15-30

[2] LM Prasad, "Organizational Behavior", Sultan Chand \& Sons, ed 2003. Zeeshan Amir, "Job satisfaction and perception of quality of work life", Management Dynamics and Integrating World Market published by SMS, MNNIT, Allahabad ed 2003,4.28-4.36

[3] Pareek U (1993), Making organizational roles effective, Tata Mc Graw -Hill, N.Delhi.

[4] Harrison R V (1976), ,Job stress as person-environment misfit",presented at the annual meeting of the American Psychological Association, Washington,DC.

[5] Robbins S P and Sanghi S(2006).Organizational Behavior, Dorling Kindersley (India) pvt ltd., P 542,N.Delhi 